\title{
Critical Review of the La-Zn System
}

\author{
A. Berche, M.-C. Record* and J. Rogez
}

Institut Matériaux, Microélectronique, Nanoscience de Provence - IM2NP- UMR 6242 CNRS, Université Aix-Marseille III, Faculté des Sciences et Techniques de Saint-Jérôme, Avenue Escadrille Normandie Niémen, 13397 Marseille Cedex 20, France

\begin{abstract}
All the available data on phase equilibria, thermodynamic and structural properties of the lanthanum-zinc phases are presented and critically analysed in this paper. Although these data allow to draw an overall description of the binary system, they are not accurate enough for further extrapolations to higher order systems using computational methods. Therefore at the end of this analysis we suggest new experimental investigations to improve the description of this system.
\end{abstract}

Key Words: Lanthanum, zinc, phase diagram, thermodynamic properties.

\section{INTRODUCTION}

The low densities of Mg-Zn alloys make them very attractive for applications in transport industry. However, because of their weak mechanical performances, they cannot be used without additives. Recently it was shown that the addition of Rare Earth metals (RE) can strongly improve these mechanical properties [1-3] and thus, the studies of the RE-Mg-Zn systems become of great interest.

The optimisation of these alloys requires knowledge on thermal and chemical stabilities and consequently, on phase diagrams. For systems containing more than four constituents, the phase equilibria are generally calculated by using the CalPhaD method. However, these calculations need accurate experimental information on the constitutive binary and ternary systems.

The aim of this work is to gather all the information reported in literature on the La-Zn system, to critically analyse these data and to suggest further experimental investigations that are required to provide a more accurate description of the La-Zn system.

\section{SOLID PHASES}

Five compounds, namely $\mathrm{LaZn}, \mathrm{LaZn}_{2}, \mathrm{LaZn}_{4}, \mathrm{LaZn}_{8}$ and $\mathrm{LaZn}_{13}$ are reported in the Massalski's La- $\mathrm{Zn}$ phase diagram [4] which is mainly drawn from Rolla et al. data [5]. However, a comprehensive analysis of the literature shows the identification of eight compounds, namely $\mathrm{LaZn}, \mathrm{LaZn}_{2}$, $\mathrm{LaZn}_{4}, \mathrm{LaZn}_{5}, \mathrm{La}_{3} \mathrm{Zn}_{22}, \mathrm{La}_{2} \mathrm{Zn}_{17}, \mathrm{LaZn}_{11}, \mathrm{LaZn}_{13}$. Structural data and melting points of the intermediate phases of the La-Zn system are reported in Table $\mathbf{1}$

The available information can be summarized as follows.

*Address correspondence to this author at the IM2NP- UMR 6242 CNRS, case 142 - Université Aix-Marseille III, Faculté des Sciences et Techniques de Saint-Jérôme - Avenue Escadrille Normandie Niémen, 13397 Marseille Cedex 20, France; Tel: +33(0)491288877; Fax: +33(0)491288775;

E-mail: m-c.record@univ-cezanne.fr
LaZn (50 at. \% Zn) crystallizes in a fec structure $(\mathrm{CsCl}-$ type) which was first resolved by Iandelli et al. [6]. The cell parameters were determined by several authors [6-7] within $2 \%$ of agreement.

According to Rolla et al. this phase congruently melts at 1088K [5].

$\operatorname{LaZn}_{2}(66.67$ at. \% Zn) was first reported by Rolla et al. [5]. Fornasini et al. [8] identified the crystal structure to be similar to that of the $\mathrm{CeCu}_{2}$ Laves phase. The cell parameters were determined by Fornasini et al. [8] and Veleckis et al. [9] within $0.5 \%$ of agreement.

A congruent melting was evidenced for this phase $[5,10]$. Depending on the authors, two temperatures were reported (1128 K [5] and $1125 \mathrm{~K} \mathrm{[10]).}$

$\mathbf{L a Z n}_{4}$ (80 at. \% Zn) was first identified in 1941 by Rolla et al. [5]. Later on, in 1961, Gschneider [11] reported the existence of a new compound $\left(\mathrm{LaZn}_{5}\right)$ which is closed to $\mathrm{LaZn}_{4}$ in composition, though without mentioning the latter compound. A further analysis [12] showed that both $\mathrm{LaZn}_{4}$ and $\mathrm{LaZn}_{5}$ coexist.

The crystalline structure of $\mathrm{LaZn}_{4}$ was described by Bruzzone et al. [12] as "probably an orthorhombic distortion of the $\mathrm{BaAl}_{4}$-type" structure.

Combining thermal analysis measurements and Tamman's method, Rolla et al. [5] determined an invariant peritectic decomposition of that phase at $1144 \mathrm{~K}$.

$\operatorname{LaZn}_{5}$ (83.3 at. \% Zn) crystallizes in the $\mathrm{CaCu}_{5}$-type hexagonal structure [13]. By analogy with the Ce-Zn system, Veleckis et al. [9] suggested $\operatorname{LaZn}_{5.25}$ as being the exact stoichiometry for this phase.

Schramm [14] performed differential thermal analysis on alloys with compositions ranging from 80.5 to 87.1 at. \% $\mathrm{Zn}$. Both on heating and cooling, he clearly showed the existence of an invariant reaction at $1137 \mathrm{~K}$. This transition could be associated either to the $\mathrm{LaZn}_{4}$ or the $\mathrm{LaZn}_{5}$ decompositions. 
Table 1. Literature Data on the Intermediate Solid Phases of the La-Zn System

\begin{tabular}{|c|c|c|c|c|c|c|c|}
\hline \multirow[t]{2}{*}{ Phase } & \multirow[t]{2}{*}{ at. $\% \mathrm{Zn}$} & \multirow[t]{2}{*}{ Melting Point (K) } & \multirow[t]{2}{*}{ Space Group (Number) } & \multicolumn{3}{|c|}{ Cell Parameters (̊̊) } & \multirow[t]{2}{*}{ Ref. } \\
\hline & & & & $\mathbf{a}$ & $\mathbf{b}$ & c & \\
\hline \multirow{2}{*}{$\mathrm{LaZn}$} & \multirow{2}{*}{50.0} & & Pm-3m (221) & $3.75(2)$ & - & - & {$[6]$} \\
\hline & & & Pm-3m (221) & $3.760(5)$ & - & - & [7] \\
\hline \multirow{3}{*}{$\mathrm{LaZn}_{2}$} & \multirow{3}{*}{66.7} & 1125 & - & - & - & - & [10] \\
\hline & & & Imma (74) & 4.689 & 7.638 & 7.593 & [8] \\
\hline & & & Imma (74) & $4.67(7)$ & $7.61(5)$ & $7.55(2)$ & [9] \\
\hline $\mathrm{LaZn}_{4}$ & 80.0 & $1144^{*}$ & - & - & - & - & [5] \\
\hline $\mathrm{LaZn}_{5}$ & 83.3 & & $\mathrm{P} 6 / \mathrm{mmm}$ (191) & 5.416 & - & 4.217 & [14] \\
\hline \multirow[t]{2}{*}{$\mathrm{La}_{3} \mathrm{Zn}_{22}$} & \multirow[t]{2}{*}{88.0} & $1205^{*}$ & - & - & - & - & [14] \\
\hline & & & I4 1 /amd (141) & $8.97(1)$ & - & $21.48(5)$ & [15] \\
\hline \multirow[t]{5}{*}{$\mathrm{La}_{2} \mathrm{Zn}_{17}$} & \multirow[t]{5}{*}{89.5} & 1247 & - & - & - & - & [5] \\
\hline & & 1235 & - & - & - & - & [14] \\
\hline & & & $\mathrm{R}-3 \mathrm{~m}(166)$ & $9.131(4)$ & - & $13.334(5)$ & [16] \\
\hline & & & & $(9.125)$ & - & $(8.896)$ & [9] \\
\hline & & & R-3m (166) & $9.1315(3)$ & - & $13.3340(5)$ & [17] \\
\hline \multirow{2}{*}{$\mathrm{LaZn}_{13}$} & \multirow{2}{*}{92.8} & & & $12.079-12.096$ & & & [9] \\
\hline & & & & 12.096(5) & - & - & {$[16]$} \\
\hline
\end{tabular}

*peritectic decomposition.

If one considers that the temperature $1144 \mathrm{~K}$ corresponds to the decomposition of $\mathrm{LaZn}_{4}$ as reported in Ref. [5], we can assume that $1137 \mathrm{~K}$ is the temperature of the peritectoid decomposition of $\mathrm{LaZn}_{5}$ following the reaction $\mathrm{LaZn}_{5}=$ $\mathrm{LaZn}_{4}+\mathrm{La}_{3} \mathrm{Zn}_{22}$.

$\boldsymbol{L a}_{3} \boldsymbol{Z n}_{22}$ (88 at. \%Zn) was first described as $\mathrm{LaZn}_{7.3}$ by Veleckis et al. [9]. Later on, Kripyakevich et al. [15] determined the cell parameters of this phase using an analogy with the $\mathrm{Pu}_{3} \mathrm{Zn}_{22}$ structure. Therefore we will retain the $\mathrm{La}_{3} \mathrm{Zn}_{22}$ formula for this phase.

Using differential thermal analysis, Schramm [14] evidenced an invariant reaction at $1205 \mathrm{~K}$ for a composition around 88 at. \% $\mathrm{Zn}$. This thermal phenomenon can be attributed to the peritectic decomposition of $\mathrm{La}_{3} \mathrm{Zn}_{22}$. However, the observed temperature might be underestimated as it was determined on cooling.
$\boldsymbol{L a}_{2} \boldsymbol{Z} \boldsymbol{n}_{17}$ (89.5 at. \% Zn) was first reported by Gschneider [11]. Prior to Gschneider's work two phases, namely $\mathrm{LaZn}_{8}$ (88.8 at. $\% \mathrm{Zn})$ and $\mathrm{LaZn}_{9}(90.0$ at. $\% \mathrm{Zn})$, were reported around 89.5 at. $\% \mathrm{Zn}$. Based on an analogy with the Th-Ni system, Gschneider propose to replace $\mathrm{LaZn}_{8}$ and $\mathrm{LaZn}_{9}$ by $\mathrm{La}_{2} \mathrm{Zn}_{17}$.

Based on structural studies performed on single crystals of $\mathrm{Ho}_{2} \mathrm{Zn}_{17}$ and $\mathrm{Th}_{2} \mathrm{Zn}_{17}$, Iandelli et al. [16] suggested that whatever the $\mathrm{RE}$ element, $\mathrm{RE}_{2} \mathrm{Zn}_{17}$ compounds crystallize in the same structure. This assumption was confirmed by Siegrist et al. [17] for $\mathrm{La}_{2} \mathrm{Zn}_{17}$ by measuring the cell parameters of this phase. These cell parameters were also determined by Iandelli et al. [16] and Veleckis et al. [9]. Note however that Veleckis and co-workers used the $\mathrm{Th}_{2} \mathrm{Ni}_{17}$ structure to determine the cell parameters of $\mathrm{La}_{2} \mathrm{Zn}_{17}$. Hence Veleckis' parameters cannot be considered as reliable. 
Schramm [14] and Rolla et al. [5] found a congruent melting for $\mathrm{La}_{2} \mathrm{Zn}_{17}$ at $1235 \mathrm{~K}$ and $1247 \mathrm{~K}$ respectively.

$\operatorname{LaZn}_{11}$ (91.6 at. \% Zn) was first observed by Schramm [14]. According to Sanderson et al. [18], this phase crystallizes in the $\mathrm{BaCd}_{11}$ structure. The cell parameters were determined by Sanderson et al. [18] and Iandelli et al. [16] within $1 \%$ of agreement.

According to Schramm et al [14], $\mathrm{LaZn}_{11}$ is stable up to $983 \mathrm{~K}$. Above this temperature, $\mathrm{LaZn}_{11}$ peritectically decomposes to give $\mathrm{La}_{2} \mathrm{Zn}_{17}$ and liquid. Kovalevskii et al. [19] observed the $\mathrm{LaZn}_{11}$ phase at $1000 \mathrm{~K}$. This is not consistent with the above mentioned Schramm proposition. However, thermal analysis measurements performed on three alloys with compositions closed to that of $\mathrm{La}_{2} \mathrm{Zn}_{17}$ and $\mathrm{LaZn}_{11}$ show an invariant transition at $991 \mathrm{~K}$ which is still not explained.

$\operatorname{LaZn}_{13}$ (92.8 at. \% Zn) which is the zinc richest phase was first observed by Rolla et al. [5]. Kuz'ma et al. [20] showed that the structure of this phase is similar to that of the $\mathrm{NaZn}_{13}$ cubic phase. Veleckis et al. [9] determined the cell parameter of $\mathrm{LaZn}_{13}$. As they found values ranging from $12.079 \AA$ to $12.096 \AA$, they concluded that $\mathrm{LaZn}_{13}$ is not a stoichiometric phase. However, they did not define the homogeneity range with accuracy.

The cubic cell parameter of this phase was also determined by Iandelli et al. [16] and Kuz'ma et al. [20]. Iandelli's value corresponds to Veleckis' highest one while the cell parameter determined by Kuz'ma et al. [20] agrees within $0.2 \%$ with Veleckis' lowest one.

An invariant reaction was observed at $1113 \mathrm{~K}$ both by Rolla et al. [5] and Iandelli et al. [16]. This reaction is associated by the former authors to the peritectic decomposition "LaZn $13=\mathrm{La}_{2} \mathrm{Zn}_{17}+$ liquid". By contrast, the latter authors attributed this reaction to the peritectic decomposition " $\mathrm{LaZn}_{11}=\mathrm{La}_{2} \mathrm{Zn}_{17}+$ liquid".

As mentioned earlier in this section, an invariant transition which could not be interpreted was reported at 991 $\mathrm{K}$ by Schramm [14] for alloys with compositions ranging from $\mathrm{La}_{2} \mathrm{Zn}_{17}$ to $\mathrm{LaZn}_{11}$.

To obtain a consistent phase diagram we could propose a peritectic transition for $\mathrm{LaZn}_{13}$ (liquid $+\mathrm{La}_{2} \mathrm{Zn}_{17}=\mathrm{LaZn}_{13}$ ) at $1113 \mathrm{~K}$ and a solid-solid transformation for $\mathrm{LaZn}_{11}$ at 991 $\mathrm{K}\left(\mathrm{La}_{2} \mathrm{Zn}_{17}+\mathrm{LaZn}_{13}=\mathrm{LaZn}_{11}\right)$. However, such an interpretation is not consistent with the results of Kovalevskii et al. [19] who reported $\mathrm{LaZn}_{11}$ as a stable phase at $1000 \mathrm{~K}$. As a consequence, new measurements have to be performed in the zinc richest part of the La-Zn phase diagram.
Finally, it is worthwhile to note that no solubility in pure $\mathrm{La}$ and $\mathrm{Zn}$ phases were reported in the literature.

\section{PHASE EQUILIBRIA}

All the investigations of the $\mathrm{La}-\mathrm{Zn}$ phase diagram reported in literature are listed in Table $\mathbf{2}$.

\section{Invariant Equilibria}

Rolla et al. [5] are the only authors who investigated the lanthanum richest part of the La-Zn phase diagram. However they did not mentioned the two well known phase transformations of pure lanthanum, namely dhcp-La $=$ fcc-La and fcc-La = bcc-La (see Ref. [21]). According to Gschneidner [11], Rolla et al. [5] used low purity La (98\%) for the synthesis of their alloys. This might explain why the phase transformations were not mentioned and the reported melting point of La was $100 \mathrm{~K}$ lower than the reference melting temperature provided by [21]. Therefore, for compositions lower than 10 at. \% Zn, Rolla's results are doubtful.

Twelve binary invariant equilibria were found in literature. Their characteristics are gathered in Table $\mathbf{3}$.

The melting temperatures of the intermediate phases have already been discussed in the previous section. Regarding to the additional equilibria, they correspond to four eutectics:

Eutectic 1 (liquid = fcc-La $+\mathrm{LaZn}$ ) was observed by Rolla et al. [5] at $803 \mathrm{~K}$. Using Tamman's method, the eutectic composition was estimated to amount to 22 at. \%.

Eutectic 2 (liquid $=\mathrm{LaZn}+\mathrm{LaZn}_{2}$ ) was found by Rolla et al. [5] at $1033 \mathrm{~K}$ with a eutectic composition of 56.5 at. \% Zn. A weak thermal effect was observed by Michel et al. [10] at $1047 \mathrm{~K}$ for an alloy containing 66.66 at. \% $\mathrm{Zn}$. This effect was attributed to an allotropic transformation in the $\mathrm{LaZn}_{2}$ compound. However, since such transformations were never reported so far for REZn ${ }_{2}$ type compounds, this thermal effect can be attributed to the eutectic 2 provided that the composition of the sample was richer in lanthanum than expected. Because of this discrepancy, the temperature of this eutectic should to be checked.

Eutectic 3 (liquid $=\mathrm{LaZn}_{2}+\mathrm{LaZn}_{4}$ ) was observed by Rolla et al. [5] on several alloys. The corresponding temperatures show a large dispersion (Fig. 1). The values range from $1038 \mathrm{~K}$ to $1066 \mathrm{~K}$ with an average value of $1055 \mathrm{~K}$. Using Tamman's method, the eutectic composition was estimated to amount to 73.4 at. $\% \mathrm{Zn}$.

Schramm [14] also observed the eutectic 3 though at the temperature of $1029 \mathrm{~K}$. However, the observed temperature

Table 2. Investigations on the La-Zn Phase Diagram

\begin{tabular}{|l|l|l|l|}
\hline \multirow{2}{*}{ Experimental Method } & \multicolumn{2}{c|}{ Studied Ranges } & \multicolumn{2}{c|}{ Ref. } \\
\cline { 2 - 4 } & Temperature (K) & Composition (at. \% Zn) \\
\hline \hline Direct Thermal Analysis (heating) -TA & $600-1250$ & $0-100$ & {$[5]$} \\
\hline Direct Thermal Analysis (heating and cooling) -TA & $600-1250$ & $75-100$ & {$[14]$} \\
\hline Differential Thermal Analysis (heating) - DTA & $900-1150$ & 66.7 & {$[10]$} \\
\hline E.m.f. measurements & $700-1000$ & $97-100$ & {$[22]$} \\
\hline
\end{tabular}


Table 3. Invariant Reactions in the La-Zn System

\begin{tabular}{|c|c|c|c|c|}
\hline \multirow[t]{2}{*}{ Reaction Type } & \multirow[t]{2}{*}{ Reaction (on Cooling) } & \multicolumn{2}{|c|}{ Invariant Compositions and Temperatures } & \multirow[t]{2}{*}{ Ref. } \\
\hline & & At. \% Zn & $\mathbf{T}(\mathbf{K})$ & \\
\hline Congruent melting -LaZn & liquid = LaZn & 50.0 & 1088 & {$[5]$} \\
\hline Eutectic 2 & liquid $=\mathrm{LaZn}+\mathrm{LaZn}_{2}$ & 56.5 & 1033 & [5] \\
\hline \multirow[t]{2}{*}{ Congruent melting - $\mathrm{LaZn}_{2}$} & \multirow[t]{2}{*}{ liquid $=\mathrm{LaZn}_{2}$} & \multirow[t]{2}{*}{66.7} & 1128 & {$[5]$} \\
\hline & & & 1125 & [10] \\
\hline Eutectic 3 & liquid $=\mathrm{LaZn}_{2}+\mathrm{LaZn}_{4}$ & 73.4 & 1055 & {$[5]$} \\
\hline Decomposition of $\mathrm{LaZn}_{4}$ & Uncertain & 80.0 & 1144 & [5] \\
\hline Congruent melting $-\mathrm{La}_{2} \mathrm{Zn}_{17}$ & liquid $=\mathrm{La}_{2} \mathrm{Zn}_{17}$ & 89.5 & 1235 & {$[14]$} \\
\hline Decomposition of $\mathrm{LaZn}_{11}$ & Uncertain & 91.6 & 983 & {$[14]$} \\
\hline \multirow[t]{2}{*}{ Decomposition of $\mathrm{LaZn}_{13}$} & \multirow[t]{2}{*}{ Uncertain } & \multirow[t]{2}{*}{92.8} & 1113 & {$[5]$} \\
\hline & & & 1113 & {$[14]$} \\
\hline \multirow[t]{2}{*}{ Invariant 4} & \multirow[t]{2}{*}{ liquid $=(\mathrm{Zn})+\mathrm{LaZn}_{13}$} & $\cong 100$ & 688 & {$[14]$} \\
\hline & & $\cong 100$ & 694 & [5] \\
\hline
\end{tabular}

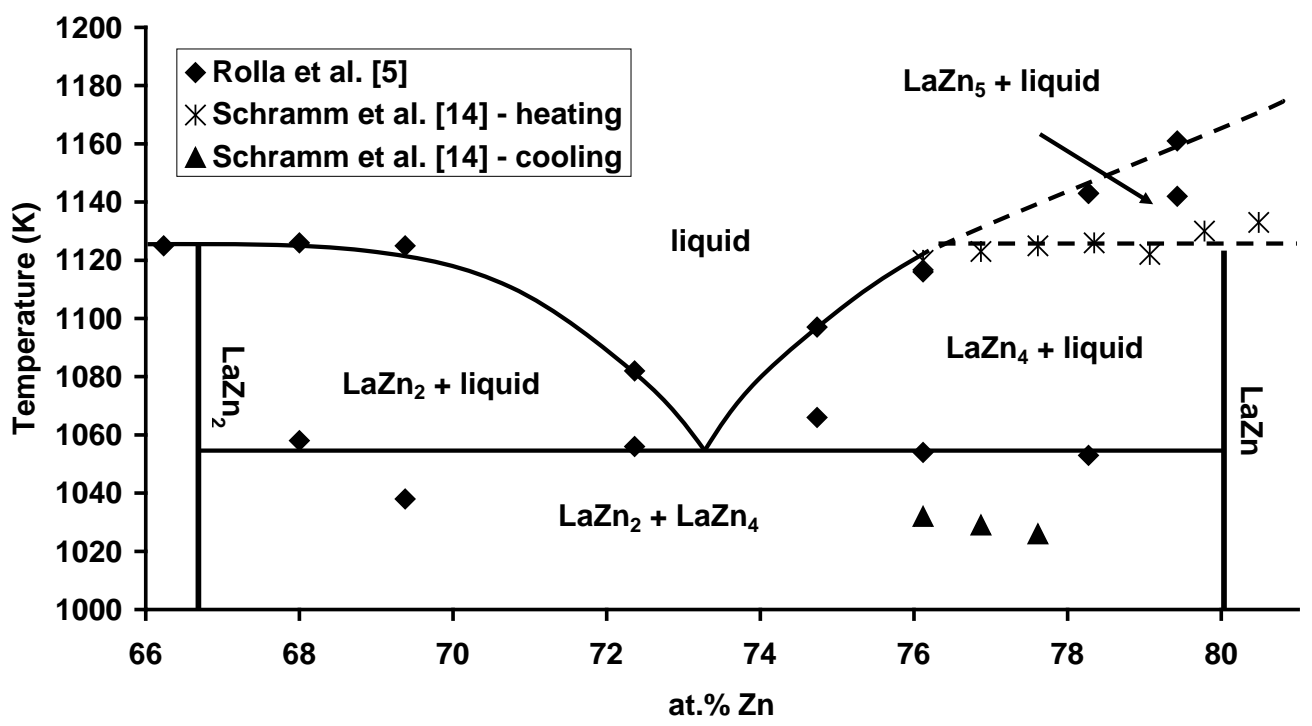

Fig. (1). The La-Zn phase diagram from 66 to 81 at. $\% \mathrm{Zn}$.

might be underestimated as it was determined on cooling. Therefore we will discard this value.

Eutectic 4 was found by Schramm [14] and Rolla et al. [5] at $688 \mathrm{~K}$ and $694 \mathrm{~K}$, respectively. No reaction was attributed to this eutectic. However as the reference melting point of $\mathrm{Zn}(692.73 \mathrm{~K})$ provided by SGTE [21] lies within the range $688-694 \mathrm{~K}$, two possibilities can be envisaged. This reaction could either correspond to a eutectic or a degenerated peritectic. Additional investigations are necessary to firmly conclude on the characteristics of this invariant reaction.

\section{Liquidus Curve}

Rolla et al. [5] are the only authors who performed measurements in the composition range 0-66 at. \% Zn (Fig. 2). As mentioned before, due to the low purity of the lanthanum used in the synthesis of the samples, the results in the La-rich domain are not reliable.

Both Rolla et al. [5] and Schramm [14] investigated the composition range 66-89 at. \% $\mathrm{Zn}$. All the available data are presented in Fig. (3). As the liquidus curves obtained by these authors between 76 and 84 at. \% $\mathrm{Zn}$ 


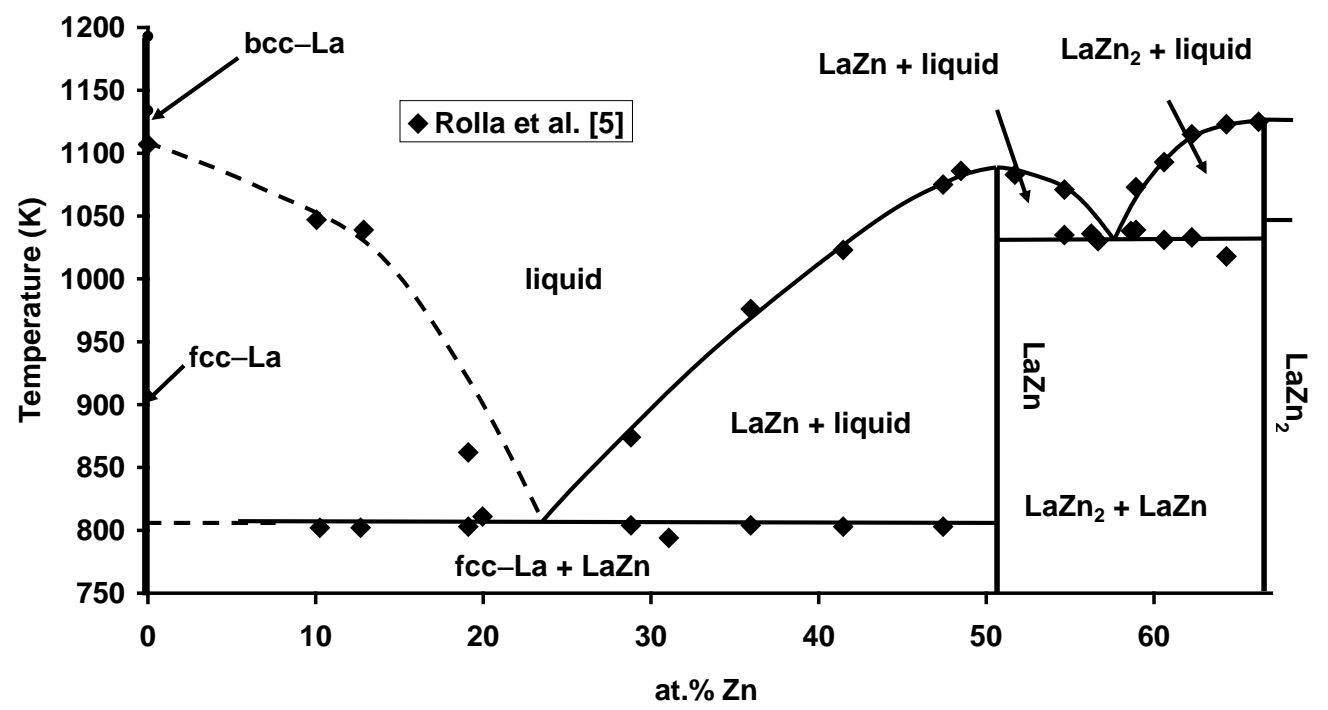

Fig. (2). The La-Zn phase diagram from 0 to 66 at.\% $\mathrm{Zn}$.

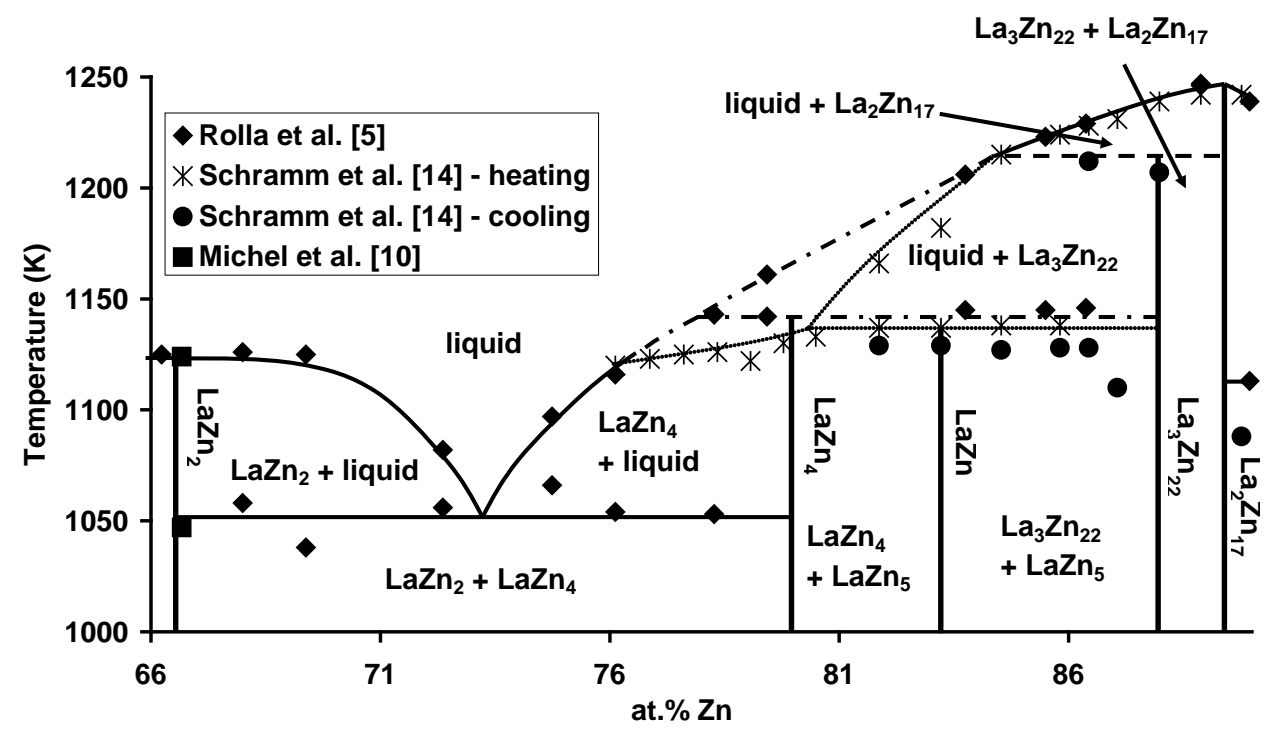

Fig. (3). The La-Zn phase diagram from 66 to 89 at. $\% \mathrm{Zn}$.

disagree with each other and because only one compound (either $\mathrm{LaZn}_{4}$ [5] or $\mathrm{LaZn}_{5}$ [14]) was considered in each of these works, this part of the phase diagram must be clarified by additional investigations.

The equilibria in the composition range 89-100 at. \% $\mathrm{Zn}$ are presented in Fig. (4). The liquidus curves determined by Rolla et al. [5] and Schramm [14] are in good agreement. In the zinc richest part of this composition domain, the liquidus curve was determined by Lebedev et al. [22] from electromotive force (e.m.f) measurements. As expected from the large difference in temperature (about $400 \mathrm{~K}$ ) between the melting point of an alloy with 98 at. $\% \mathrm{Zn}$ and that of pure zinc, we can notice a very sharp slope for this curve (about $\left.300 \mathrm{~K}(\text { at. } \%)^{-1}\right)$. In such a case, only e.m.f measurements are able to provide reliable liquidus curve.

In conclusion, from all the literature data, the phase diagram depicted in Fig. (5) can be proposed. However some discrepancies still remain and accurate, additional experimental investigations are needed to provide a clear picture of the La-Zn phase diagram.
These investigations should focus on the La-rich part of the phase diagram (up to 25 at. $\% \mathrm{Zn}$ ) which is still unknown, on the determination of the temperature of the eutectic 2 (liquid $=\mathrm{LaZn}+\mathrm{LaZn}_{2}$ ), on the elucidation of the existence of $\mathrm{LaZn}_{4}$ and $\mathrm{LaZn}_{5}$ phases, on the liquidus curve in the composition range $75-89$ at. $\% \mathrm{Zn}$ and finally on the stability ranges of $\mathrm{LaZn}_{11}$ and $\mathrm{LaZn}_{13}$.

\section{THERMODYNAMIC DATA}

All the thermodynamic investigations on solid phases reported in literature are listed in Table 4.

E.m.f. measurements were performed in the temperature range $700-1000 \mathrm{~K}$ in the zinc rich part of the La-Zn phase diagram [23-25]. All the results are plotted in Fig. (6). An overall agreement is observed. Except for Mullayanov et al. [24] who indicated a composition range of 95.0-98.6 at. \% $\mathrm{Zn}$ for their alloys, the other authors did not give values for the studied compositions. According to the La-Zn phase diagram, at those temperatures and for compositions higher than about 93 at.\% $\mathrm{Zn}$, the alloys are constituted of a liquid in equilibrium with the solid phase $\mathrm{LaZn}_{13}$. However in their 


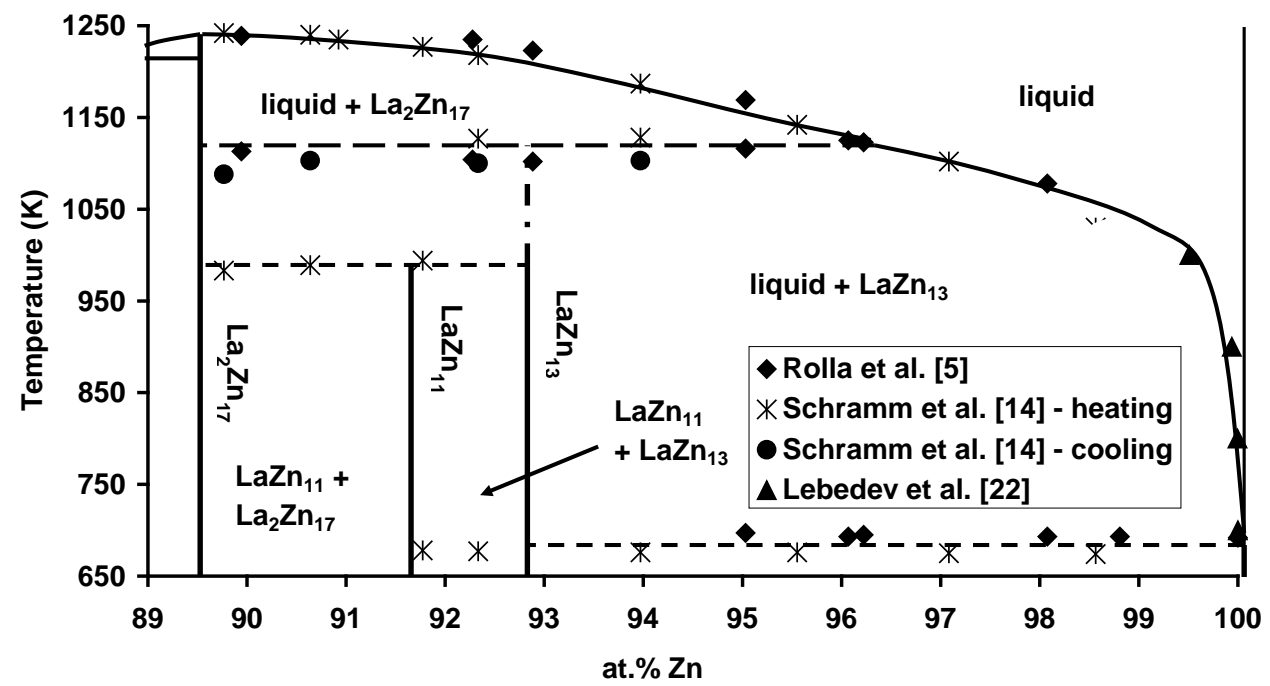

Fig. (4). The La-Zn phase diagram from 89 to 100 at.\% $\mathrm{Zn}$.

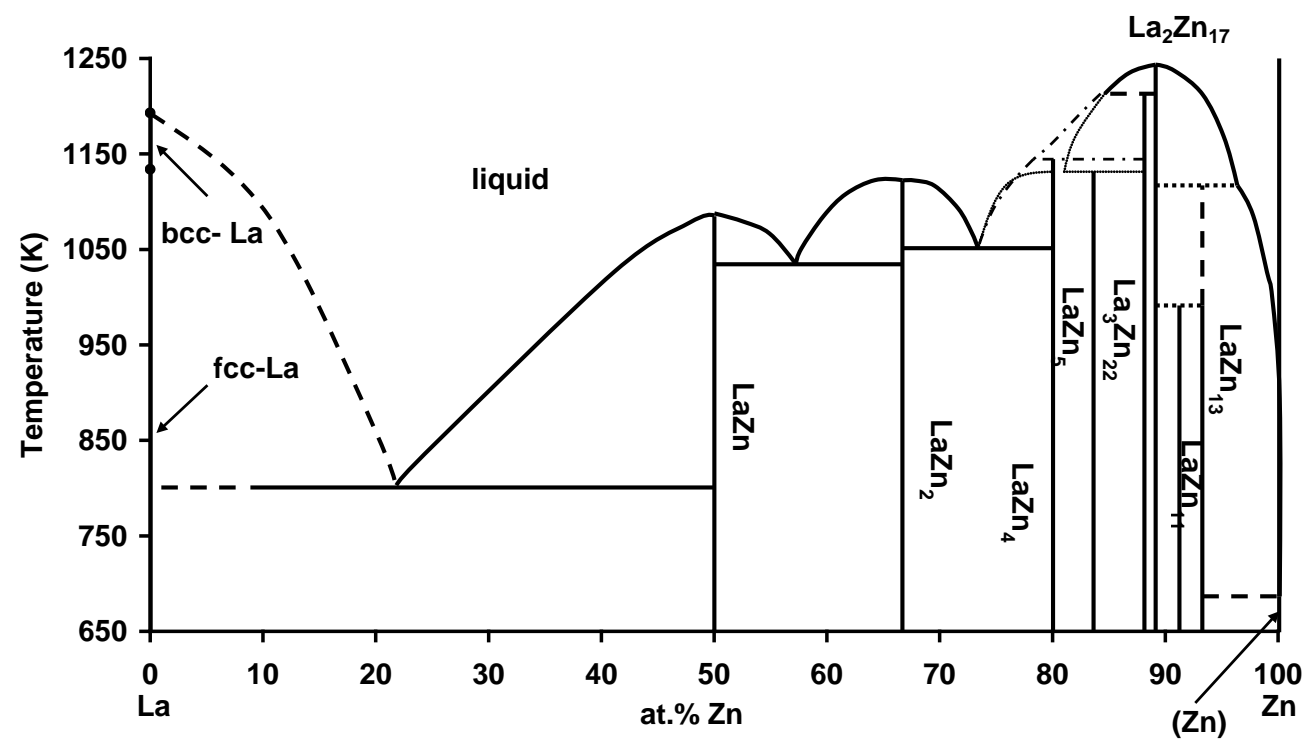

Fig. (5). Most reliable phase diagram after critical review of the literature data.

Table 4. Thermodynamic Investigations in the La-Zn System

\begin{tabular}{|c|c|c|c|}
\hline Investigation Method & Temperature Range (K) & Studied Phases & Ref. \\
\hline e.m.f. & $730-1030$ & $\mathrm{LaZn}, \mathrm{LaZn}_{2}, \mathrm{LaZn}_{4}, \mathrm{LaZn}_{5}, \mathrm{La}_{3} \mathrm{Zn}_{22}, \mathrm{La}_{2} \mathrm{Zn}_{17}, \mathrm{LaZn}_{11}$ & [19] \\
\hline e.m.f. & $870-1020$ & $\mathrm{LaZn}_{13}+$ liquid & {$[24]$} \\
\hline e.m.f. & $700-800$ & $\mathrm{LaZn}_{13}+$ liquid & [25] \\
\hline DFT calculations & 0 & $\mathrm{LaZn}, \mathrm{LaZn}_{2}, \mathrm{LaZn}_{5}, \mathrm{La}_{2} \mathrm{Zn}_{17}$ & [26] \\
\hline $\begin{array}{l}\text { Solution calorimetry (in } \mathrm{HCl} \text { ) } \\
\text { Relaxation method }\end{array}$ & $2-300$ & $\mathrm{LaZn}_{13}$ & [27] \\
\hline Direct calorimetry & 745 & liquid & {$[28]$} \\
\hline
\end{tabular}

papers, the authors attributed the solid phase to $\mathrm{LaZn}_{11}$. This mistake is caused by the fact that the authors did not perform samples analyses and based the interpretation of their results on a wrong phase diagram. The partial enthalpy, entropy and Gibbs energy of lanthanum determined from these e.m.f. measurements are reported in Table $\mathbf{5}$. 
Kovalevskii et al. [19] investigated by e.m.f. measurements the whole range of compositions of the La-Zn phase diagram at $1000 \mathrm{~K}$. The interpretation of these results in the light of previous literature data led the authors to consider seven stable compounds, namely $\mathrm{LaZn}, \mathrm{LaZn}_{2}, \mathrm{LaZn}_{4}$, $\mathrm{LaZn}_{6}, \mathrm{LaZn}_{8}, \mathrm{LaZn}_{9}$ and $\mathrm{LaZn}_{11}$. However this interpretation disagrees with our analysis regarding the phase stoichiometry. A new interpretation of Kovalevskii's results at $1000 \mathrm{~K}$ was presented in Ref. [26]. This interpretation of e.m.f. measurements is in agreement with our suggested phase diagram. The differences between these two interpre- tations for Kovalevskii's results could be explained by zinc evaporation in the zinc richest samples.

In the same study, Kovalevskii et al. [19] investigated the evolution of the e.m.f. with respect to temperature for alloys selected from each two-phase region. The investigated temperatures ranged from 700 to $1120 \mathrm{~K}$. From these data, the partial Gibbs energies of lanthanum are calculated at $1000 \mathrm{~K}$ (see Table 5). Table 6 gives the partial enthalpies and entropies determined from the new interpretation of Kovalevskii's measurements [26].

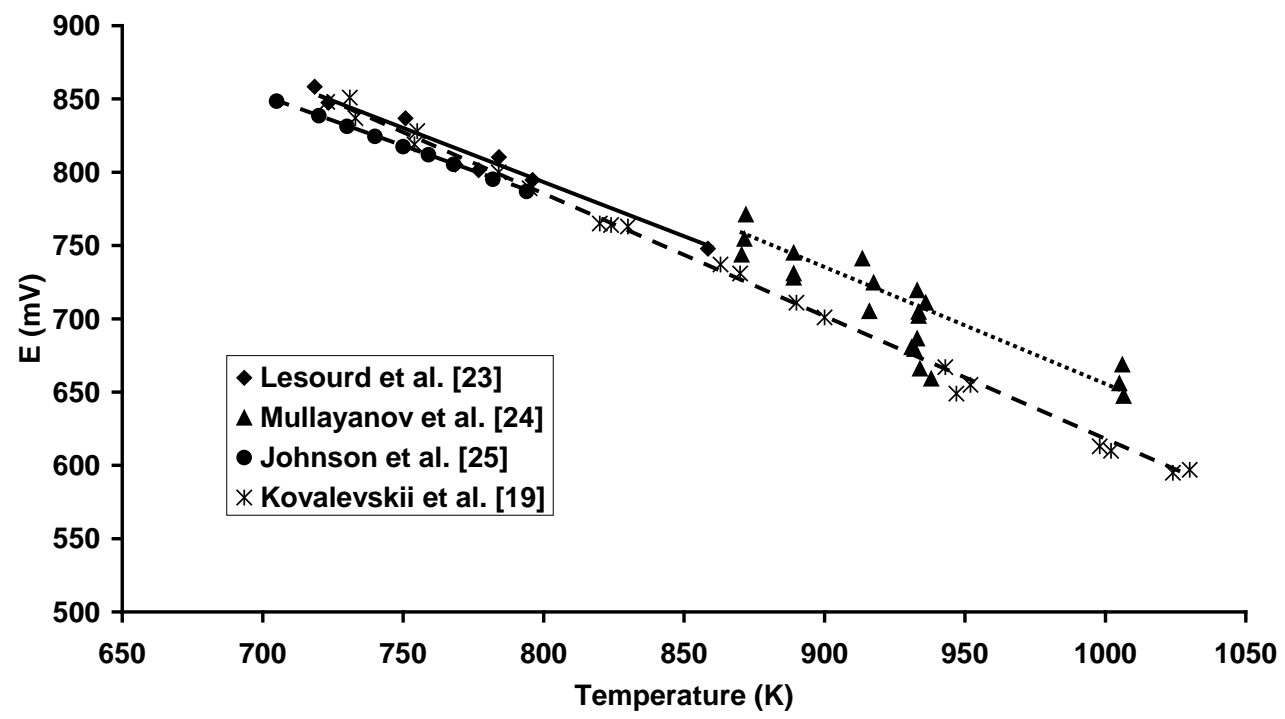

Fig. (6). E.m.f. measurements on two-phase (liquid+solid) alloys belonging to the zinc-richest part of the phase diagram with respect to temperature.

Table 5. Partial Enthalpy, Entropy and Gibbs Energy of Lanthanum Determined from e.m.f Measurements. The Partial Gibbs Energy is Calculated at $\mathbf{T}$

\begin{tabular}{|c|c|c|c|c|}
\hline$\overline{\Delta H}_{\mathrm{La}}\left(\mathrm{kJ}\right.$ Mol Atom $\left.{ }^{-1}\right)$ & $\overline{\Delta S}_{\text {La }}\left(\mathbf{J}\right.$ Mol Atom $\left.{ }^{-1} \mathbf{K}^{-1}\right)$ & $\overline{\Delta G}_{\text {La }}\left(\mathrm{kJ}\right.$ Mol Atom $\left.{ }^{-1}\right)$ & $\mathbf{T}(\mathbf{K})$ & Ref. \\
\hline-387.4 & -200.8 & - 186.6 & 750 & [25] \\
\hline$-391.3 \pm 0.7$ & $-223.4 \pm 0.8$ & $-167.9 \pm 1.5$ & 1000 & [22] \\
\hline$-393.8 \pm 5.9$ & $-216.5 \pm 14.2$ & $-177.2 \pm 0.8$ & 1000 & [19] \\
\hline
\end{tabular}

Table 6. Partial Enthalpy, Entropy and Gibbs Energy of La Calculated at $1000 \mathrm{~K}$ from the New Interpretation of the Kovalevski et al. Measurements [19] by Berche et al. [26]

\begin{tabular}{|c|c|c|c|}
\hline at. $\% \mathrm{Zn}$ & $\overline{\Delta H}_{\mathrm{La}}\left(\mathrm{kJ}\right.$ Mol Atom $\left.{ }^{-1}\right)$ & $\overline{\Delta S}_{\text {La }}\left(\mathbf{J ~ M o l ~ A t o m ~}^{-1} \mathbf{K}^{-1}\right)$ & $\overline{\Delta G}_{\mathrm{La}}\left(\mathrm{kJ}\right.$ Mol Atom $\left.^{-1}\right)$ \\
\hline 91.60 to 99.51 & $-394.1 \pm 5.9$ & $-216.7 \pm 14.2$ & $-177.4 \pm 0.8$ \\
\hline 88.00 to 89.50 & $-171.1 \pm 13.3$ & $-53.1 \pm 14.2$ & $-118.0 \pm 3.3$ \\
\hline 83.30 to 88.00 & $-90.0 \pm 13.4$ & $+4.6 \pm 13.0$ & $-94.6 \pm 3.3$ \\
\hline 66.67 to 80.00 & $-61.5 \pm 9.2$ & $-2.9 \pm 9.6$ & $-58.6 \pm 3.3$ \\
\hline 50.00 to 66.67 & $-6.7 \pm 2.5$ & $+5.4 \pm 11.7$ & $-12.1 \pm 1.3$ \\
\hline 0.00 to 50.00 & 0.0 & 0.0 & 0.0 \\
\hline
\end{tabular}


Morishita et al. [27] investigated the thermodynamic properties of the $\mathrm{LaZn}_{13}$ phase. The sample was synthesized from pure elements (Zn, 99.9 wt. \% and La, 99.99 wt. \%) in a high-frequency induction melting furnace. According to the microprobe and X-ray diffraction analyses, a single phase material was obtained. The enthalpy of formation of this sample was measured at $298 \mathrm{~K}$ by calorimetry in a $5 \mathrm{~N}$ hydrochloric solution. By using a relaxation method, these authors also measured the heat capacity of the sample in the temperature range $2-300 \mathrm{~K}$. The Gibbs energy of $\mathrm{LaZn}_{13}$ at $298 \mathrm{~K}$ was deduced from these results by Morishita and coworkers.

Recently, Berche et al. [26] determined the heat content $\mathrm{H}^{\mathrm{T}}-\mathrm{H}^{298}$ of $\mathrm{La}_{2} \mathrm{Zn}_{17}$ between room temperature and $665 \mathrm{~K}$ using the drop calorimetry method. A comparison between this value and that obtained using the Kopp-Neumann rule suggests a negligible excess heat capacity (see Table 7).

Table 7. Heat Contents of $\mathrm{La}_{2} \mathrm{Zn}_{17}$

\begin{tabular}{|c|c|c|}
\hline \multirow[t]{2}{*}{$\mathbf{T}(\mathbf{K})$} & \multicolumn{2}{|c|}{$\mathrm{H}^{\mathrm{T}}-\mathrm{H}^{298}\left(\mathrm{~kJ}(\mathrm{Mol} \text { of Atom })^{-1}\right)$} \\
\hline & Calorimetry & Kopp-Neumann \\
\hline 665 & $9.1 \pm 0.6^{1}$ & 10.0 \\
\hline 910 & $15.2 \pm 0.3^{2}$ & 16.7 \\
\hline
\end{tabular}

${ }^{1}$ experiment; ${ }^{2}$ linear extrapolation of experimental results from $665 \mathrm{~K}$ to $910 \mathrm{~K}$.

In the same study, Berche et al. [26] performed solution calorimetry measurements at $665 \mathrm{~K}$ in tin bath to determine the enthalpies of formation of the $\mathrm{La}-\mathrm{Zn}$ intermediate phases at $298 \mathrm{~K}$. The result obtained for $\mathrm{LaZn}_{13}$ agrees with Morishita's value [27] within the uncertainty limit (see Fig. 7). The enthalpies of formation of $\mathrm{LaZn}, \mathrm{LaZn}_{2}, \mathrm{LaZn}_{5}$ and $\mathrm{La}_{2} \mathrm{Zn}_{17}$ were also calculated at $0 \mathrm{~K}$ by Berche et al. [26] using Density Functional Theory (DFT) calculations. The theoretical results are compared to those obtained experimentally by the same authors in Table 8 and in Fig. (7). A good agreement is observed even though the enthalpies of formation were determined at different temperatures $(0 \mathrm{~K}$ and $298 \mathrm{~K})$. This observation could support our previous statement that the excess heat capacity is low for the La- $\mathrm{Zn}$ phases. The enthalpy of formation of the intermediate phases of the La-Zn system were also estimated by Berche et al. [26] from Kovalevskii's measurements in the temperature range $700-1120 \mathrm{~K}$. The values are given in Table 8 . The heat contents and average heat capacities of the La- $\mathrm{Zn}$ compounds were then determined by Berche et al. [26] for temperatures between $298 \mathrm{~K}$ and $910 \mathrm{~K}$. These quantities were deduced from the difference of the enthalpies of formation of the La-Zn compounds between $298 \mathrm{~K}$ and $910 \mathrm{~K}$. They are reported in Table 9 . Note that $910 \mathrm{~K}$ corresponds to the average temperature of the temperature range investigated by Kovalevskii. The heat content of $\mathrm{La}_{2} \mathrm{Zn}_{17}$ reported in Table 9 $\left(12.0 \mathrm{~kJ} \mathrm{~mol}^{-1}\right)$ is in relative good agreement with that reported in Table $7\left(15.2 \pm 0.3 \mathrm{~kJ} \mathrm{~mol}^{-1}\right)$ which was obtained from linear extrapolation of the experimental values from $665 \mathrm{~K}$ to $910 \mathrm{~K}$.

Finally, the partial enthalpy of mixing of lanthanum in liquid zinc at $745 \mathrm{~K}$ was determined by Berche [28] using direct solution calorimetric measurements. The results are

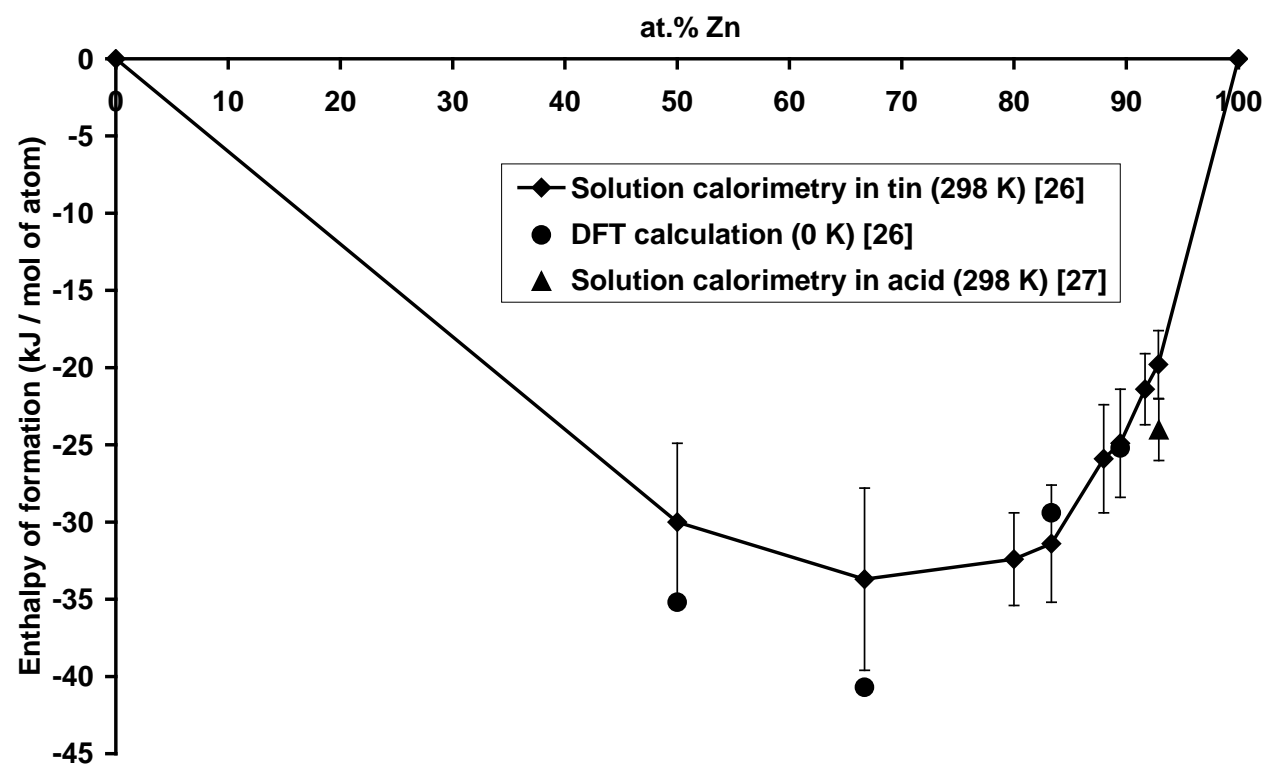

Fig. (7). Enthalpies of formation of solid La-Zn phases at $0 \mathrm{~K}$ and $298 \mathrm{~K}$ from [26].

Table 8. Enthalpies of Formation of the La-Zn Intermediate Phases (in kJ (Mol of Atom) ${ }^{-1}$ ) Determined in [26]

\begin{tabular}{|c|c|c|c|c|c|c|c|c|}
\hline $\mathbf{T}(\mathbf{K})$ & LaZn & $\mathbf{L a Z n}_{2}$ & $\mathrm{LaZn}_{4}$ & $\mathbf{L a Z n}_{5}$ & $\mathbf{L a}_{3} \mathbf{Z n}_{22}$ & $\mathbf{L a}_{2} \mathbf{Z n}_{17}$ & $\operatorname{LaZn}_{11}$ & $\mathbf{L a Z n}_{13}$ \\
\hline 298 & $-30.0 \pm 5.1$ & $-33.7 \pm 5.9$ & $-32.4 \pm 3.0$ & $-31.4 \pm 3.8$ & $-25.9 \pm 3.5$ & $-24.9 \pm 3.5$ & $-21.4 \pm 2.3$ & $-19.8 \pm 2.2$ \\
\hline 0 & -35.2 & -40.9 & - & -29.4 & - & -25.2 & - & - \\
\hline $700-1120$ & $-36.2 \pm 3.1$ & $-46.1 \pm 3.3$ & $-43.0 \pm 2.0$ & $-41.8 \pm 1.6$ & $-39.1 \pm 0.5$ & $-37.1 \pm 0.9$ & $-32.2 \pm 0.9$ & - \\
\hline
\end{tabular}


Table 9. Heat Contents $\left(\mathrm{H}^{\mathrm{T}}-\mathrm{H}^{298}\right.$ in $\left.\mathrm{kJ} \mathrm{Mol}^{-1}\right)$ and Average Heat Capacities (Cp in $\left.\left.\mathrm{J}(\mathrm{Mol} \text { of Atom })^{-1} \mathrm{~K}^{-1}\right){ }^{[26}\right]$

\begin{tabular}{|c|c|c|c|c|c|c|c|}
\hline & \multicolumn{7}{|c|}{ Solid Compounds } \\
\cline { 2 - 8 } & $\mathbf{L a Z n}$ & $\mathbf{L a Z n}_{\mathbf{2}}$ & $\mathbf{L a Z n}_{\mathbf{4}}$ & $\mathbf{L a Z n}_{\mathbf{5}}$ & $\mathbf{L a}_{\mathbf{3}} \mathbf{Z n}_{\mathbf{2 2}}$ & $\mathbf{L a}_{\mathbf{2}} \mathbf{Z n}_{\mathbf{1 7}}$ & $\mathbf{L a Z n}_{\mathbf{1 1}}$ \\
\hline \hline $\mathrm{H}^{\mathrm{T}}-\mathrm{H}^{298}$ & 15.3 & 10.3 & 13.0 & 13.5 & 11.0 & 12.0 & 13.6 \\
\hline $\mathrm{C}_{\mathrm{p}}$ & 25.1 & 16.9 & 21.3 & 22.0 & 17.9 & 19.6 & 22.3 \\
\hline
\end{tabular}

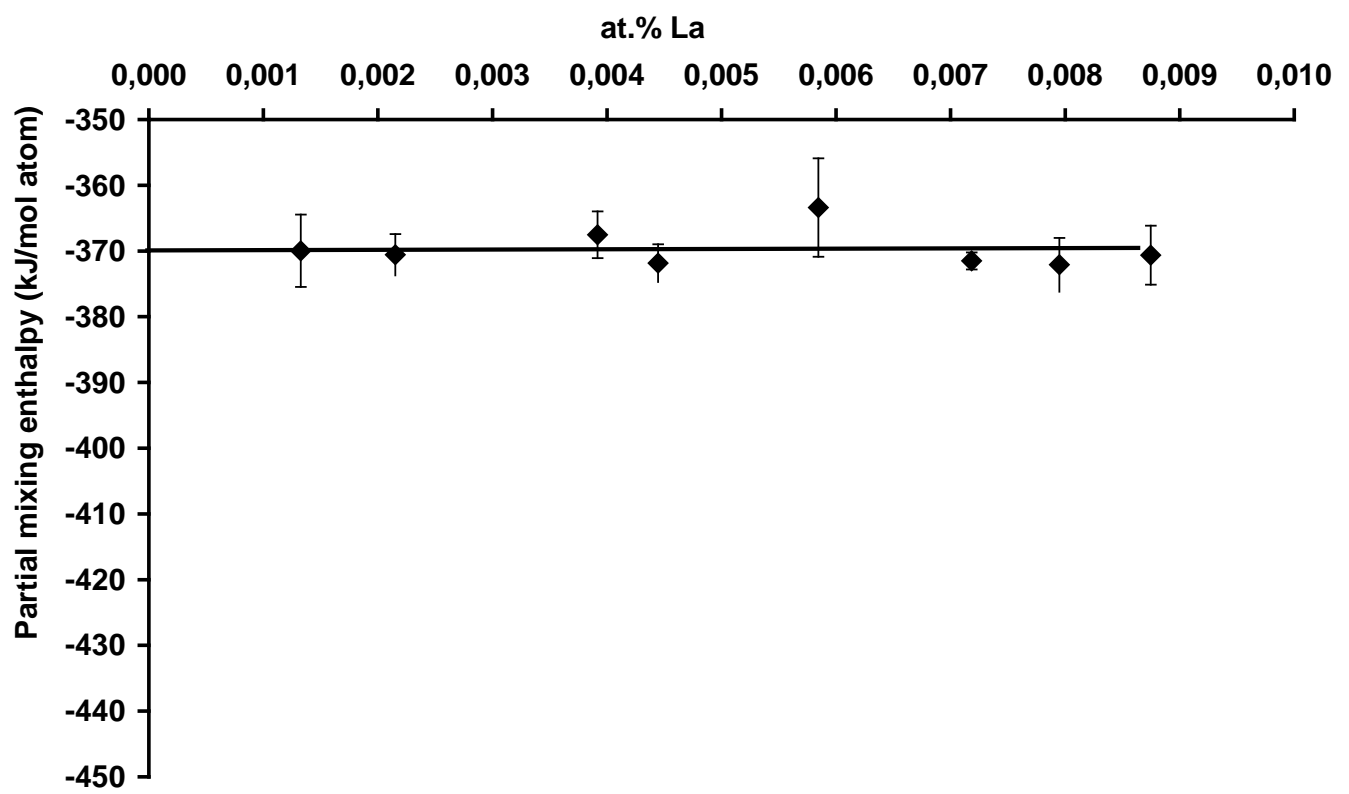

Fig. (8). Partial enthalpy of mixing of lanthanum in liquid zinc at $745 \mathrm{~K}$ [28].

presented in Fig. (8). The value of the partial enthalpy of mixing of $\mathrm{La}$ in liquid zinc at $745 \mathrm{~K}$ at infinite dilution amounts to about $-370 \mathrm{~kJ}$ (mol of atom) $)^{-1}$.

\section{CONCLUSION}

The La-Zn phase diagram reported in Massalski's compilation [4] is only based on the experimental data of Rolla et al. [5]. In this work, we propose a new phase diagram that accounts for the whole reliable set of data available in literature. Even though the description of this phase diagram is incomplete and because some doubts remain due to discrepancies between the literature data, the main phase equilibria are described.

Among the eight solid compounds $\mathrm{LaZn}, \mathrm{LaZn}_{2}, \mathrm{LaZn}_{4}$, $\mathrm{LaZn}_{5}, \mathrm{La}_{3} \mathrm{Zn}_{22}, \mathrm{La}_{2} \mathrm{Zn}_{17}, \mathrm{LaZn}_{11}$ and $\mathrm{LaZn}_{13}$, only $\mathrm{LaZn}_{13}$ presents a nonstoichiometric domain. $\mathrm{LaZn}_{\mathrm{Z}} \mathrm{LaZn}_{2}$ and $\mathrm{La}_{2} \mathrm{Zn}_{17}$ melt congruently whereas $\mathrm{La}_{3} \mathrm{Zn}_{22}$ decomposes peritectically. The reactions involving each of the $\mathrm{LaZn}_{4}, \mathrm{LaZn}_{5}$, $\mathrm{La}_{3} \mathrm{Zn}_{22}, \mathrm{LaZn}_{11}$ and $\mathrm{LaZn}_{13}$ phases deserve new investigations. New measurements are also required in the La- and Zn-rich regions and the characteristics of the eutectic equilibrium "liquid $=\mathrm{LaZn}+\mathrm{LaZn}_{2}$ " must be clarified. Furthermore, the compositions range $76-86$ at. $\% \mathrm{Zn}$ must be reinvestigated.

Regarding the thermodynamic data, they have already been determined for solid phases. However, only a few thermodynamic information is available on the liquid phase.

\section{REFERENCES}

[1] L.Y. Wei, G.L. Dunlop, and H. Westengen, "The intergranular microstructure of cast $\mathrm{Mg}-\mathrm{Zn}$ and $\mathrm{Mg}-\mathrm{Zn}$-Rare Earth alloys", Metall. Mater. Trans. A, vol. 26(8), pp.1947-1955, August 1995.

[2] L.Y. Wei, G.L. Dunlop, and H. Westengen, "Precipitation hardening of Mg-Zn and Mg-Zn-RE alloys", Metall. Mater. Trans. A, vol. 26(7), pp. 1705-1716, July 1995.

[3] W. Wu, Y. Wang, X. Zheng, L.J. Chen, and Z. Liu, "Effect of neodynium on mechanical behavior of $\mathrm{Mg}-\mathrm{Zn}-\mathrm{Zr}$ magnesium alloy”, J. Mater. Sci. Lett., vol. 22(6), pp. 445-447, March 2003.

[4] T.B. Massalski, Binary Alloys Phase Diagrams, American Society for Metals: Materials Park (Ohio), 1990.

[5] L. Rolla, and A. Iandelli, "Metals and alloys of the rare earths. I. The system lanthanum-zinc", Ric. Sci., vol. 12, pp. 1216-1226, December 1941.

[6] A. Iandelli, and E. Botti, "The crystal structure of some intermetallic compounds of the rare earths", Gazz. Chim. Ital., vol. 67, pp. 638-644, December 1937.

[7] J. Pierre, A.P. Murani, and R.M. Galera, "Magnetic-susceptibility, electrical-resistivity and neutron spectroscopy of some cubic cerium intermetallics", J. Phys. F. Met. Phys., vol. 11(3), pp. 679698, November 1981.

[8] M.L. Fornasini, F. Merlo, and G.B. Bonino, "Compounds of the formula $\mathrm{MX}_{2}$ formed by the reaction of rare earths with zinc", Atti Accad. Naz. Lincei Rend. Cl. Sci. Fis. Mat. Nat., vol. 43(5), pp. 357-363, May 1967.

[9] E. Veleckis, R.V. Schablaske, I. Johnson, and H.M. Feder, "Intermetallic phases in the systems of zinc with lanthanum, cerium, praseodymium, neodymium and yttrium", Trans. Metall. Soc. AIME, vol. 239(1), pp. 58-63, January 1967.

[10] D.J. Michel, and E. Ryba, "Melting points of REZn $n_{2}$ intermetallic compounds", J. Less Common Met., vol. 11(1), pp. 67-69, July 1966. 
[11] K.A. Gschneider, Rare Earth Alloys, Van Nostrand: Princeton NJ, 1961.

[12] G. Bruzzone, M.L. Fornasini, and F. Merlo, "Rare-earth intermediate phases with zinc", J. Less Common Met., vol. 22(3), pp. 253264, November 1970.

[13] H. Nowotny, "The crystal structure of $\mathrm{Ni}_{5} \mathrm{Ce}, \mathrm{Ni}_{5} \mathrm{La}, \mathrm{Ni}_{5} \mathrm{Ca}, \mathrm{Cu}_{5} \mathrm{La}$, $\mathrm{Cu}_{5} \mathrm{Ca}, \mathrm{Zn}_{5} \mathrm{La}, \mathrm{Zn}_{5} \mathrm{Ca}, \mathrm{MgCe}, \mathrm{MgLa}$ and $\mathrm{MgSr}$ ", Z. Met. Kd., vol. 34(11), pp. 247-253, November 1942.

[14] J. Schramm, "The systems zinc-cerium and zinc lanthanum", $Z$. Met. Kd., vol. 33(10), pp. 358-360, October 1941.

[15] P.I. Kripyakevich, Yu.B. Kuz'ma, and N.S. Ugrin, "Crystalline structure of $\mathrm{Ce}_{3} \mathrm{Zn}_{22}, \mathrm{La}_{3} \mathrm{Zn}_{22}$, and $\operatorname{Pr}_{3} \mathrm{Zn}_{22}$ compounds", J. Struct. Chem., vol. 8(4), pp. 632-633, July 1967.

[16] A. Iandelli, and A. Palenzona, "Zinc-rich phases of the rare-earth-zinc alloys", J. Less Common Met., vol. 12(5), pp. 333-343, May 1967.

[17] T. Siegrist, and Y. Le Page, "Crystal chemistry of some $\mathrm{Th}_{2} \mathrm{Zn}_{17^{-}}$ type rare-earth-zinc phases", J. Less Common Met., vol. 127, pp. 189-197, January 1987.

[18] M.J. Sanderson, and N.C. Baenziger, "The crystal structure of BaCd $_{11}$ ", Acta Crystallogr., vol. 6(7), pp. 627-631, July 1953.

[19] A.V. Kovalevskii, V.A. Lebedev, I.F. Nichkov, and S.P. Raspopin, "Thermodynamic properties and phase composition of lanthanumzinc alloys", Izv. Akad. Nauk SSSR Met., vol. 1, pp. 183-187, January 1972.

[20] Y.B. Kuz'ma, P.I. Kripyakevich, and N.S. Ugrin, "New compounds of rare earth metals with zinc and their crystal structure", Inorg. Mater., vol. 2(4), pp. 544-548, April 1966.
[21] SGTE, Landolt-Börnstein, New Series IV/19B, pp. 1-4, 2002.

[22] V.A. Lebedev, I.F. Nichkov, S.P. Raspopin, R. Kh. Mullayanov, and B.G. Semenov, "Thermodynamics of the reaction of zinc with lanthanum and cerium", Russ. J. Phys. Chem., vol. 45(8), pp. 11261127, August 1971.

[23] J.-P.P.F. Lesourd, and J.A. Plambeck, "Electrochemical studies of lanthanum and lanthanum-zinc alloys in fused $\mathrm{LiCl}-\mathrm{KCl}$ eutectic", Can. J. Chem., Vol. 47(18), pp. 3387-3391, September 1969.

[24] R.K. Mullayanov, V.A. Lebedev, Y.P. Kanashin, I.F. Nichkov, and S.P. Raspopin, "Thermodynamics of a lanthanum-zinc system", Russ. J. Phys. Chem., vol. 43(11), pp. 1559-1561, November 1969.

[25] I. Johnson, and R.M. Yonco, "Thermodynamics of cadmiumand zinc-rich alloys in the cadmium-lanthanum, cadmium-cerium, zinc-lanthanum, zinc-cerium, and zinc-praseodymium systems", Metall. Trans., vol. 1(4), pp. 905-910, April 1970.

[26] A. Berche, F. Marinelli, G. Mikaelian, J. Rogez, and M-C Record, "Enthalpies of formation of the La-Zn compounds between 298K and $910 \mathrm{~K}$. Experimental and theoretical investigations", J. Alloys Compd. (2008), doi: 10.1016/j.jallcom.2008.07.060. [Online]. Available: www.sciencedirect.com/science/journal/09258388

[27] M. Morishita, K. Koyama, and K. Tsuboki, "Calorimetric study of $Z_{13}$ La”, Z. Met. Kd., vol. 95(8), pp. 708-712, August 2004.

[28] A. Berche, "Contribution à l'étude thermodynamique du système Lanthane-Magnésium-Zinc (La-Mg-Zn)", Ph-D Thesis, Aix Marseille University, Marseille, France, 2007.

(C) Berche et al.; Licensee Bentham Open.

This is an open access article licensed under the terms of the Creative Commons Attribution Non-Commercial License (http://creativecommons.org/licenses/bync/3.0/) which permits unrestricted, non-commercial use, distribution and reproduction in any medium, provided the work is properly cited. 